\title{
Exploration and Reflection on Teachers' Self-Growth under Network Environment
}

\author{
Shuang Li \\ Department of Education, Dezhou University, Dezhou 253023, China \\ E-mail: Lishuang305@163.com
}

\begin{abstract}
As is well known, it is network that has turned the traditional "man-man" educational system made up of by only teachers and students into a new system of "man-machine-man" composed of network as well as teachers and students. In the new system, teachers' authority has been lowered sharply because students also have access to teachers' knowledge from the internet at any time and as a result teachers are faced with newer and higher requirements for their comprehensive abilities. Therefore, only by relocating themselves, developing and perfecting themselves constantly, developing their abilities in conformity to the present network era and equipping themselves with a series of necessary qualities can they really control the commanding point and take the commitment of educating people as well as importing knowledge.
\end{abstract}

Keywords: Network environment, Teachers, Education, Self-growth

\section{Updating their Reserve of Knowledge and Ability Constantly}

Under the network environment, students receive new knowledge with incomparable width, depth and speed. Teachers' long-reserved knowledge is far from enough to satisfy students' demands with the higher speed of knowledge renewal and development. Accordingly, they are supposed to keep pace with the era to learn, to update and enrich their knowledge structure, to enlarge their horizon, to grasp the latest academic development, hence guaranteeing their systematic, advanced and rich knowledge reserve. Only in this way will they be able to have current knowledge input, to teach students in accordance with their aptitude and therefore to satisfy students' individualized demands.

\section{Making Greater Efforts in Reflection and Creation}

Although the conversion from the fixed reserve of knowledge to the constantly-updated one mainly involves a quantitative accumulation, we have to ponder on the qualitative aspect. Is it a simple reproduction or a refinement process of reflection and creation? In the current information-filled network society, quality is not so easy to achieve while quantity seems to be a piece of cake. With the network society characterized by copying others without reflection, people's reflective and creative abilities have been devoured by the network unconsciously. Innovation is of great value in such a situation. Teachers are expected to have their judgments, choices, reflections and innovations to decide whether to accept or reject something and to give guidance to their students who fail to find their way in such an information-filled world, just like wise fishermen guiding those aimless fishes in the broad ocean. Only by having constant reflections and innovations as well as encouraging their students to do so will teachers be the winner of the network era.

\section{Having More Interactions with Students for Joint Growth}

It has been long accepted that teachers should be equipped with much more knowledge than that they give to their students. However, this is not totally true in the present network environment. With faster knowledge renewal, the disparity between teachers and students in knowledge tends to be narrower. Sometimes, it is impossible for teachers to equip themselves with all the necessary knowledge before conveying hem to their students. Consequently, under the network environment, teachers' role in imparting knowledge has given way to that as the designer and organizer of teaching activities as well as the instructor of students. Teachers are expected to receive new knowledge from books and internet together with students in order to realize their values and their self-growth as well as to help their students to achieve progress. Actually, a wise and confident teacher should be courageous enough to learn from their students as well in order to achieve their goals with constant two-way communications between them. Such an interactive teaching and learning process, due to both sides' totally equal status, means dialogue, participation and mutual construction. It is not only a way to conduct teaching activities but an educational circumstance and spiritual atmosphere established between teachers and students. For students, it means an opportunity to open their mind, to expose their subjectivity, to advocate their individualities as well as to set free their creativeness; for teaches, it means a new definition of teaching: not conveying knowledge but a process to share understandings, to develop and to realize self-values. 


\section{Converting Themselves into Guides to Cultivate Students into Innovative Talents}

In the current network society, students' styles of cognition and thinking have been changed a lot and their creativity and activity are being fully stimulated. As a result, teachers have to conduct effective teaching in conformity to these changes. Brand new educational ideas have to be established to convert pure teaching into guidance, to turn students' passive learning into active one and to change the process of receiving knowledge into the one of constructing knowledge. Accordingly, instead of inputting their knowledge into students once it is demanded, teachers should have their role converted into guides for students., just like drawing a cup of water with a spoon of water, drawing a bucket of water with a cup of water and finally drawing endless water flow with a bucket of water. This is also a process for students to construct and accumulate knowledge and to fully exert their potentials, which is the very nature of learning and the fundamental purpose of education. The book Learning to Survive: Today and Tomorrow of Education compiled by UNESCO elaborates on teachers' role: stimulating reflection instead of conveying knowledge. In addition to their formal roles, teachers tend to be more like advisors, referrers with whom students can exchange ideas and instructors who help to find out contradictory arguments instead of putting forward truths directly.

\section{Being Equipped with Good Information Literacy}

Information literacy was defined by ITAA President Paul Zurkowski in 1974 as the technologies and skills employed to solve problems with a large amount of information tools and major information resources. Afterwards, with deeper researches on information literacy, different definitions appeared. Based on comprehensive analysis, in my opinion, it should be defined as a person's attitudes toward information activities , his ability in acquiring, analyzing, processing, evaluating, innovating and transmitting information and his ability to judge what information is required, where to acquire it as well as how to acquire, process and transmit information. Overall, information can be divided into information sense, information knowledge, information ability and information morality. In such a complete system, information sense serves as the precondition, information ability as the core and information morality guides the overall direction. In the network era, teachers' importance is no longer reflected in the amount of knowledge and skills they convey to students, but how to teach them to acquire, analyze, extract information from internet. Professor Haoqiang Tan, a well-known expert in computer science, says that the standards to measure talents have been changed from knowledge accumulation into knowledge search and creation and information literacy should be a basic ability to acquire formerly unknown knowledge with the least time and the most effective method. Therefore, favorable information literacy is an ability equally important as listening, speaking, reading, writing and calculation in the $21^{\text {st }}$ century and should be added into teachers' comprehensive abilities.

\section{Adapting Their Traditional Task to the Cultivation Goal of the New Era}

In the modern society, since students have access to what their teachers have obtained through long-time learning with a click on the mouse, teachers are no longer the only source of knowledge and their authority is challenged to a large extent. However, when faced with the shock of multi-culture including sex, violence as well as internet games, some students unable to discipline themselves tend to be lost, leading to their declined values and morality as well as deficient personality. Therefore, the task of educating them seems to be of particular importance in the new situation. In addition, the sharper social conflicts are, the more diversified value orientations will be, the more necessary teachers' guidance will be. With both opportunities and challenges given by the new era, the task of educating people seems more important than that of conveying knowledge. Accordingly, teachers are expected to explore new-style cultivation pattern in conformity to the network era to provide students with more influences, choices, service and guidance instead of too much persuasion or sermon.

\section{Saving the Weaker Teacher-Student Relationship with Patience, Sense of Responsibility and Kindness}

With no doubt, as teachers' authority as the carrier of knowledge is lessened and students don't admire them any longer, the teacher-student relationship has more color of equality, democracy and looseness and their interaction tends to be emotion-free. However, it is teachers' personality that still exerts profound influences on students. According to Russian educator Ushinski, all in education should be based on personality for the power of education can only pour out of the source of teachers' personality; there will be no real education without direct influences on students' personality; especially in the current society, the imbalance of human nature, such as spiritual emptiness, personality corruption, indifferent interpersonal relationship brought about by the development of science and technology as well as benefiting themselves at the expense of others, money worship and officials' corruption caused by people's pursuit for economic benefits, makes teachers' personality more valuable. It is even claimed that teachers' personality is all of education. Only with perfect personality will teachers take the commitment of shaping students with respectful, independent, scientific and healthy 
personalities.

Showing patience, doing their duties and loving students are still the most fundamental parts in teachers' personality structure as well as the basis for harmonious teacher-student relationship. In spite of wonderful and attractive things on it, internet is really merciless and mechanic. Only by strengthening human nature and personality, such as love and caring, keen observation, independent thinking and sound personality, can the emotional emptiness brought about by the network world be compensated and harmonious teacher-student relationship be reconstructed. As a result of their harmonious relationship with teachers, students tend to be interested in what their teachers teach them.

\section{Strengthening Their Ethical, Moral and Legal Ideas and Improving Their Information Immunity in both Virtual and Real Environments}

Currently, internet, by changing our styles of working, learning, entertainment and thinking, has become the second living space or living environment for human beings. Its quality determines that of people's living. It is no wonder why Nicholas Negroponte says that the computer is not only related to calculation but determines our living and we must try to shape a safe digital environment consciously. In such a second living environment, teachers are expected to guide their students to protect the environment and practice green consumption, such as strengthening legal ideas, following the game rules in the virtual space, maintaining the normal order of the virtual space, avoid disseminating false and harmful information, improving discrimination and immunity to harmful information, strengthening self-control, self-discipline and self-coordination. Just as what Ushinski once said, only when you are devoted to self-education will you be able to educate others. Therefore, teachers are supposed to have sound ethical, moral and legal ideas to take the responsibility of influencing students with their morality and personality in the new era.

\section{References}

Hu, Chunmei. (2005). Reconstruction and Teacher-Student Relationship under the Network Environment. Teaching and Management. 12: pp34-35.

Luo, Lujing. (2008). A Study on Education Science Based on the Network Environment. Science and Technology Information. 16: p16.

Tian, Linghui. (2006). Network Education: A Challenge to the Traditional View of Teachers and Students. Education Science. 2: pp26-27.

Xia, Shi. Feng, Minying. (2008). A Study on New Teacher-Student Relationship in Universities under the Network Environment. Ethics and Morality. 12: p48.

Ye, Lan. et al. (2001). New Exploration into Teachers' Role and Development (1st edition). Beijing: Educational Science Publishing House. 